\title{
Debating "the Social": Towards a Critique of Sociological Nostalgia
}

\author{
Anthony Elliott ${ }^{1} *$ and Bryan S. Turner ${ }^{2}$ \\ 1 School of Social and Policy Studies, Faculty of Social and Behavioural Sciences, Flinders \\ University, GPO Box 2100, Adelaide 5001, Australia \\ 2 The Graduate Center, the City University of New York, 365 Fifth Avenue, New York, NY 10016, \\ USA
}

* Author to whom correspondence should be addressed; E-Mail: Anthony.Elliott@flinders.edu.au; Tel.: 61-8-820-13538.

Received: 8 December 2011; in revised form: 2 March 2012 / Accepted: 13 March 2012 /

Published: 22 March 2012

\begin{abstract}
Although sociology can be commonsensically and parsimoniously defined as the study of society, the problems of defining such terms as 'society', 'the social', and 'the social system' remain an ongoing irritant of sociological theory. In addition to these traditional conceptual problems, there is currently a strong sense that 'society' as an empirical reality and 'society' as a concept are in crisis. Given the contemporary view of 'the end of the social' there is also manifestly a potent and nostalgic interest in the past as a time of comforting solidarity and meaningfulness. To clarify this debate, we start by making a distinction between three approaches to society, namely structure, solidarity and creation. Nostalgia hinges around the certainties that followed from reliable social structures, and from the comfort of community. We illustrate these forms of nostalgia through an examination of the social philosophy of Alasdair MacIntyre. Recognizing that his criticisms of the loss of virtue represent a powerful indictment of modernity, we argue that past societies were also fractured by moral discord. More importantly, MacIntyre rules out the possibility of moral re-invention by excluding the rise of human rights as a moral framework. In conclusion, the forms of social creativity may not enjoy the 'sticky' solidarity of the past, but they do testify Georg Simmel's idea of the social (Vergesellschaftung).
\end{abstract}

Keywords: society; social; structure; solidarity; creation; nostalgia 


\section{Introduction}

From a commonsense point of view, sociology is 'the scientific study of society' and in this connection we have often heard that the word 'sociology' has two roots. The Latin term socius refers to friendship or comradeship and the suffix ology designates the study of something. Sociology as a modern discipline is the study of those institutions, social relationships and interactions that take place in civil society or that terrain that exists between the state and the market. This interpretation leads to the obvious conclusion that sociology is that discipline that takes social solidarity as its primary object of research. We have however also been told, by Hannah Arendt no less, that the ancient world knew nothing of 'society' but only valued the polis where free and autonomous men gathered for rational debate and the cultivation of virtue. Aristotle, in The Nicomachean Ethics, specifically contrasts human community or association (koinonia) — as foundational to the politics of a 'society or citizens' - with the private individual or household (oikos). Arendt and David Reisman debated the rise of totalitarianism in which sociology was associated with the study of mass society, and in this debate Reisman identified the 'lonely crowd' as a specific feature of society in the modern period. Yet another aspect of the history of 'society' is associated with the classic distinction between association and community in the work of Ferdinand Tönnies. The erosion of community with the growth of urbanization had serious implications for associational life and indeed for the survival of society. In Max Weber's sociology, this dichotomy was associated with the themes of rationalization and disenchantment. These preliminary observations point to a common experience in sociology, namely a persistent intellectual nervousness about the subject matter of the discipline. These difficulties are not just definitional but point to radical empirical changes in society, giving rise to the idea of 'the end of the social' [1]. There is, we would contend, in addition a strong tendency towards nostalgia in which sociological work which looks backwards historically to a world in which friendship, communities and neighborhoods flourished and in which the individual found security and meaning. By contrast, the mega-city in the age of globalization is a fleeting world of mobile strangers resulting in anomie and social dislocation [2].

This sense of unease about the social may have become more dominant in recent years, but it is certainly not a new experience. To take one example almost at random, let us consider the reflections of Albion W. Small at the University of Chicago in an article from the American Journal of Sociology in 1912 in which he asserted that the 'category of society' is merely a 'convenience' and that it is constantly being re-constructed by the observer to make sense of observations of individuals. Small of course had been influenced by Georg Simmel and we might conveniently turn to Simmel who in the early history of sociology offered the most coherent and consistent definition of its area of interest, but a definition of sociology that, if anything, emphasized the idea of the social as process rather than as institutions that are more or less constant and fixed. For Simmel, the 'eternal' is always in the snapshot of the everyday world.

Simmel's approach to sociology was developed in 1908 in Soziologie: Untersuchungen über die Formen der Vergesellschaftung in which he showed how sociology involves an inquiry into the construction of social forms in terms of their quantity, spatial distribution and ongoing structures. Through this notion of social forms, interaction and exchange, Simmel wanted to overcome the conventional division between scientific positivism and psychologism. For Simmel, social forms were 
not - to quote Émile Durkheim - external, constraining and autonomous social facts, but simply the conditions that made human action possible. The idea of society in fact covers two distinct meanings. First, there is the 'complex of interacting individuals, the socially formed human matter, as that constitutes the entire historical reality. Yet 'society' is also the sum of individual forms of relationships, by which individuals are able to become a society in the first sense' [3]. He invented a neologism to capture this perspective, namely the concept of Vergesellschaftung which illustrates his approach. In Simmel's actual usage, it referred both to social interaction and to the creation of social entities. To reflect this difference, translators of Simmel have used both 'social interaction' and 'creating society' to cover the notion of Vergesellschaftung. The important point here is that 'the social', for Simmel, always involved forms and processes rather than a reification of the social as society.

The principal aim of Simmelian sociology was to capture the fleeting and fragmented nature of modernity in which the city-dwelling individual is bombarded by signs and commodities. As a result the individual develops a blasé attitude towards urbanism in order to cope with the overwhelming abundance of experiences in the modern city. Indifference and apathy protect us against the welter of impressions and encounters. Subsequently Simmel's account of 'The Metropolis and Mental Life' [4] has become a classic of early sociology. Simmel's work has a critical edge in perceiving the tragic nature of the tensions between form and content in modernity. He followed the mood of his age in 'The Conflict of Modern Culture' in recognizing that '(1)ife can enter reality only in the form of its counter-image - that is only as form' [5]. For many social theorists, the rise of the city, the never ending flux of modernity and the erosion of community created both a melancholic interpretation of the present and a nostalgic view of the past. This pessimism was captured - or in fact re-captured from the discourse of classical political theory-in the notion of fate which became a central, if often disguised, theme in Weber's sociology [6].

This pessimistic trajectory of European society colored much of the world view of Weber in the contrast between fate and virtue, the metaphor of the iron cage and in his analysis of bureaucratization. It is probably more accurate to say that Weber was both fascinated by and fearful of the development of rational capitalism in Europe than in America. Weber's American journey is important for what it tells us in general about European attitudes to America. In Reflections on America [7] Claus Offeconsidering the responses of Tocqueville, Adorno and Weber to American society - studied both the negative and the positive commentaries of Europeans on the new world. Was the future to be the Europeanization of America or the Americanization of Europe? Lawrence Scaff carefully unpacks the complicated responses of Weber, who rejected the romantic European view of North America as the last frontier of individual freedom and at the same time, dismissed the entirely dystopic narrative of North America as a society that was already exhausted [8]. Scaff claims that for Weber North America was not the 'iron cage' and that Weber sought an 'unprejudiced comparison and analysis of the institutions and practices of social and political life under the conditions of a modern capitalism that North America shared with Europe' ([8], p. 183). The notion of 'society' in Weber's sociology was powerfully influenced by this sojourn during which he developed the notion that the sect-like associations and clubs in North America were important in binding individuals together. For Scaff, Weber was not a European pessimist of the end of society. While in 1904 Weber may have sustained optimism about the dynamic features of Anglo-American religion, he was certainly pessimistic about 
the prospects for the autonomy of the individual in a bureaucratic Germany. This may also account for his fascination with the charismatic figure of Stefan Georg and his circle-perhaps the last genuinely charismatic figure in German cultural circles [9].

\section{The Argument}

Three issues arise from these introductory comments. The first is the general problem of providing convincing definitions of a cluster of concepts that are familiar to sociologists: 'the social', 'social group', 'society', 'social system' and, more generally, 'social interaction'. The second is to take the history of such concepts seriously and the third is to ask whether 'society' has changed so radically that the legacy of classical sociology is no longer adequate to the world which we inhabit. This final issue is to examine the discourse of 'the end of the social' and to ask what catastrophes might indeed bring an end to society. Having examined a range of radical transformations of society we conclude that sociologists should avoid romantic nostalgia in assuming that the world we have lost was more integrated or that social life was more meaningful or that social solidarity was grounded in a morally coherent community. The social is constantly reinvented, but this is not to deny a variety of radical social changes that have transformed 'society'. We contrast this view of the social as for ever being reconstructed or-to use Jeffrey Alexander's vocabulary-constantly repaired with the social philosophy of Alasdair MacIntyre, whose views on historical destruction of community, and the virtues that went with it, are plausible but overly pessimistic. MacIntyre is important for any discussion of the changing character of the social, because he offers one of the most far-reaching criticisms of the loss of social solidarity with the erosion of communities as an outcome of urbanization, class formation and secularization. He draws on Weber's pessimistic view of rationalization to suggest that the Durkheimian solidarity of the past has been thoroughly undermined. Although we recognize that MacIntyre's criticisms of modern society are both powerful and evocative, we claim that his conceptual approach ignores the possibility that new and creative social networks can arise with new technologies of communication and that more importantly he neglects the emergence of a new moral vision namely the growth of human rights. In short, while recognizing the erosion of society as a tightly-knit form of solidarity, we conclude with a consideration of social creativity as a response to MacIntyre's nostalgic critique of modernity.

\section{Three Frameworks for 'Society'}

In developing our argument, we begin by suggesting that society - as both theoretical construct and lived reality — has been analyzed under three dominant frameworks. These three conceptualizationsoperating as both discursive constructions and pre-theoretical understandings - unfold around the turn of the nineteenth century and undergo various complex transformations in the twentieth century through to the contemporary period. These three distinct senses of society can be summarized as follows:

1. Society as structure;

2. Society as solidarity, or communities of concern, care and consensus;

3. Society as creative process, or the imaginary dimensions of communication and sociality. 
First, there is society as structure - a conceptualization that designates the descriptive aspects of structured competition, conflict and rivalry and the normative aspects of refinement, morals and manners. From this angle, society is abstract, alienating, and mechanically reproduced. This view of society is often, rightly or wrongly, associated with the analysis of society in the late Marx of Capital. The idea of structure was designed to capture the idea of society as an objective set of relations beyond the control and often beyond the knowledge of the individuals who were caught within this external set of relations. Second, there is society as solidarity. This notion of society is classically associated with the sociology of Durkheim, but it was in fact a widespread assumption in ninetieth-century French social thought. In this interpretation of society, solidarity is seen as being in constant tension with the ruthless individualism of capitalism rather than as subservient to, or integrated with, it. On this view, society is closely associated with affect, sentiment and passion; society promotes concern for others, care of the self, civic bonding and communal integration. The constitution and reproduction of community is a matter of engagement, dialogue, consultation and consensus. Finally, there is society as creation. Society in this sense arises when the social is constituted with explicit reference to its own self-implementation, design, construction or creation. This approach to the social is, as we have suggested, specifically associated with Simmel in the idea of the social as a never-ending process. If structure implies that society is always and already assembled, creation suggests that society has to be always and ongoingly produced and reproduced. In modern sociology, such an interpretation has been closely associated with symbolic interactionism and with action theory [10]. The phrase 'society as creation' designates that the self-institution of social relations, along with self-reflection on social life is paramount. In this tradition of thought, society involves some recognition of the role of invention, ingenuity, innovation and imagination.

The three distinct senses of society are not of course easily separated out. Anthony Giddens in his 'structuration theory', and Pierre Bourdieu, in the 'logic of practice', sought to overcome the distinctions between structure, solidarity and agency [11,12]. That is to say, these versions of societystructure, solidarity and creation - constantly cross-cut and interchange with each other conceptually and empirically. This is certainly true of how society has been signified as an analytical feature of social science, at least with reference to the three major forms of the concept throughout human history-namely, tribal societies, class-divided societies and modern nation-state societies. Especially important among intellectual evaluations of 'society' - and this is arguably so whether the societies in question were simple or primitive on the one hand, or complex and developed on the other-is the degree of 'system-ness', or integral wholeness, attributed to external forces in meeting the satisfaction of people's material needs and wants. This is certainly true of society-focused social theories, from Durkheim's emphasis on society as a whole to more recent versions of structuralism in sociology and systems theory. No matter what degree of 'system-ness' is attributed to society as a substantive entity (conceived usually as closely allied with either biological processes or informational metaphors), all structured conceptions of society make some reference-however minimal — to the beliefs, values, feelings and dispositions of the members of any given society. This is to say, if societies are to function with an adequate degree of system-ness, there must be some basic sense of 'common identity' or 'sense of belonging' to a wider collectivity. It is important here to re-emphasize that, in conceptualizing social association, social scientists theorize the orderly roles of structure, the natural sentiments of solidarity, and the inventiveness of creation differently. This issue can be seen clearly in 
post-Parsonian attempts to rethink the classical ideas of status and role in which 'social role' is always a process in which actors endlessly struggle to make sense of the norms that allegedly define any role performance. The critical point, however, is that these different versions of society appear in the literature as competing, contradictory, and unstable conceptions.

\section{On the Politics of Nostalgia}

In The Sociological Tradition, Nisbet argued that sociology was an aspect of diverse intellectual movements which were responses to the Industrial and the French Revolutions [13]. Whilst liberalism and socialism were influential, the most significant force shaping early sociology was in fact conservatism. The key 'unit ideas' of sociology such as 'authority', 'the sacred', 'community', and 'organic wholeness', are primarily aspects of this conservative legacy. Thus, sociology was an intellectual response to the sense of a lost community, the disappearance of the sacred as a source of values, the isolation of the individual in the city, and the resulting crisis of meaning. In this sense, sociology was a nostalgic reflection on the loss of authenticity, personal spontaneity, social wholeness and community. We must be careful here in our use of terminology, because in the modern world 'conservatism' might be easily identified with reactive, backward-looking thought. In Britain, the idea has also become associated with former Prime Minister Thatcher's strategy for transforming the legacy of trade unionism and in the North American context conservative values are largely identified with neo-conservatism in the Republican Party, from the legacy of former President Ronald Reagan. Although Durkheim is often associated with conservative perspectives on society, we should remember that he favored state regulation and supported economic guilds, and professional bodies to regulate trade and industry in his Professional Ethics and Civic Morals [14]. Durkheim was in his thinking about the state a socialist and in his approach to values and tradition a 'radical conservative' who was distrusted by hierarchy of the Roman Catholic Church. Durkheim's family background lay in rabbinical Judaism and in France this heritage was automatically identified with cosmopolitanism, Paris intellectuals and the political Left. Durkheim was thus a radical conservative in his (socialist) critique of rampant individualism and the disruptive force of industrial capitalism [15].

Although Durkheim's political views were complex, the themes of solidarity and community in classical sociology are components of a general paradigm of nostalgia that was redolent, not only in sociology, but more generally in western culture. In broad terms, we can identify a number of dimensions of the nostalgic imagination of the loss of society as structure and as solidarity. Firstly, there is the sense of historical decline and loss, involving a departure from some golden age. The messianic message of Old Testament Judaism and New Testament Christianity typically involved some sense of a lost space and lost time from which contemporary social systems can be measured and found wanting. Although the Abrahamic religions look into the future for an image of paradise and redemption, they can also be seen as nostalgic in their theology of grace. The fall of humanity from a perfect union with God drove Adam and Eve out of the Garden, condemning them to labor to live. This Judeo-Christian background has had a profound impact on Western thought in general and on Marxist sociology and critical theory in particular which have also often embraced a cataclysmic vision of history as a violent progression of revolutionary events into an unknown future from a garden of perfect harmony. This was a radical catastrophic world-view, and found tragic expression for 
example in the work of critical theorists such as Walter Benjamin who in the face of rising European fascism combined a mystical Jewish tradition with secular Marxist theory. The result was an eschatology or theory of the ends of history that saw the present in terms of a wind of total destruction [16].

The second component of the nostalgic reflection on society is a sense of the absence or loss of personal wholeness and moral certainty. In this dimension, human history is perceived in terms of a collapse of values which once provided the unity of human relations, knowledge and personal experience. This nostalgic theme contains a theory of secularization in which the sacred canopy of religious certainty is fractured by catastrophic social processes, typically the emergence of markets, capitalist relations and urban cultures as the negation of rural naivety. We can find this theme prominent in the philosophy of Jean-Jacques Rousseau [17]. In his nostalgic version of the social contract in 1762, there is the loss of genuine experience and the rise of an artificial world of spectacle and theatre. Rousseau's experience of Paris confirmed his view of small rural communities as the only environment where the education of children could be safely secured. In 1762, in his study of education, the young Émile will spend his time running about barefoot and with little clothing, free from the burden of books, leading the life of a natural soul free from the moral and physical pollution of the city [18]. This is a program of romantic nostalgia.

Yet another aspect of nostalgia is the sense of loss of individual freedom and autonomy with the disappearance of genuine social relationships. With secularization and the loss of moral coherence, the isolated individual is increasingly exposed to the constraining social processes of modern institutionalized regulation, which gradually undermines the individual, who is strangled within the world of state bureaucracies. This theme was one aspect of Weber's metaphor of the iron cage in which individuals were merely cogs of modern social processes. For Weber (at least in his interpretation of Germany), the modern world meant the loss of both charisma and tradition, and the overwhelming spread of rational bureaucracies. This sociological tradition was inherited by the Frankfurt critical theorists, some of whom described modern society as an administered world in which the isolated individual is wholly subordinated to the rationality of instrumental reason and capitalist relations of production. With the decline of natural law, human beings lived a world of fractured moral traditions in which perspectivism became a dominant theme of ethical theory.

What emerges from this discussion is that the contrast between the past and the present is, we argue, sociologically problematic and that, in addition, the implicit theory of the Fall prematurely cuts of the idea that community may in fact be an endless process rather than fixed historical point. While the roots of modern communal processes are fragile and the prospects of restoring communal life are dim, we must leave the possibility of communal renewal open. While recognizing that modern societies are indeed characterized by excessive individualism, low social capital and thin social relations, the social world, from the perspective of critical sociology, can always be open to renewal and reinvention.

As we have indicated above various aspects of sociological nostalgia are dominant themes in the work of MacIntyre. His historical sketches of philosophical and social changes in the development of modernity raise the suspicion that there has never been a society in the past that was blessed by coherent values and authoritative moral solutions to human dilemmas. MacIntyre only offers rather distant examples-ancient Greece and the warrior cultures of northern Europe and Iceland-of societies in which fact and value were not separate and in which personality and meaning were neatly 
combined in the social structure [19]. The modern period of historical decline in MacIntyre's scheme of things hangs on the construction of the moral theory of Aquinas. One criticism of MacIntyre would be that these societies of warriors and the Thomist institutions and values of the Middle Ages were themselves hierarchical and sharply divided, for example between clergy and laity and between warriors and peasants, and between men and women. The historical evidence at least raises a question about the degree to which these societies were characterized by some coherent moral system or a dominant ideology [20]. MacIntyre's work is therefore underpinned by a pessimistic criticism of the present and a nostalgic view of the past. Nostalgia plays an important role in critical theories of modernity and is not, at least in MacIntyre's version, in any simplistic sense a form of cultural conservatism, notwithstanding his dependence on Marxist theory [21,22].

While MacIntyre is overtly engaged with the legacy of Weber, his argument about community and resistance to individualism appears to draw more profoundly from the work of Durkheim, despite the fact that Durkheim does not make an appearance in MacIntyre's oeuvre. Certainly MacIntyre's emphasis on the importance of community has a distinctively Durkheimian flavor. In The Elementary Forms Durkheim argued that the roots of the social are ultimately in the sacred [23]. If we accept the direction of Durkheim's sociological thesis, the foundations of community are deeply rooted in the sacred and therefore the mechanisms that connect people together into communal bonds are indeed religious forces. Cultural critics of modernity recognize that the sacred roots of collective culture are being eroded by globalization in the form of commercialization and commodification; we are faced with the prospect of the unending MacDonaldization of society. In a modern commercial society, the citizen becomes merely a passive consumer of goods and services. There is in short an elective affinity between the passive citizen, modern spirituality and individualism. The 'chain of memory' that is constitutive of communal relationships has been broken by the evolution of possessive individualism in capitalist societies [24]. This interpretation of our modern dilemmas-relativism, moral incoherence, the destruction of the environment, the celebration of greed-does indeed involve a metaphysics of nostalgia.

\section{Towards a Critique of Nostalgia}

MacIntyre's work is characterized by nostalgia, because he constructs an imaginary community of the past in order to criticize the society of the present [25]. This notion that the values that had once underpinned community have been replaced by an artificial society of the present was common to much twentieth century thought. In a short note on 'society', Robert Nisbet observed that through much of the twentieth century there had been both a negative and a positive definition of society [26]. The negative view of society emerged in comparison to the idea of 'community'. Whereas society has become bureaucratic and impersonal, community was seen to enjoy a permanence and authority. This contrast had its intellectual origins in the famous argument of Ferdinand Tönnies on the distinction between community (Gemeinschaft) and association (Gesellschaft). The alternative positive meaning, however, was situated in a contrast between society and the sovereign nation state. Whereas society was the site of individual freedoms and liberties, these were all too easily expunged by the growth of the modern state. While conservatives looked back to the security of community, pluralists thought that freedom-depending heavily on the survival of voluntary associations, autonomous institutions 
and civil society - was severely compromised by the growth of the state. Nisbet concluded his note by observing that the majority of twentieth-century writers believed that modern society was in a state of crisis from which it might not emerge. MacIntyre's views on communities of the past and societies of today share this view of history as a 'great transformation' from the certainties of a coherent community to the normative chaos of community.

MacIntyre's critical framework does not allow him easily to see the possibilities for a shared moral discourse that has been opened up by the evolution of a global human rights culture. Of course, human rights have often been dismissed by critics as merely the product of western individualism. Yet, it is no longer possible to argue that this discourse of rights is simply a western invention; human rights have become the language of NGOs globally, the basis of western intervention around the world and the vocabulary of protest in Tibet, China, Egypt and Syria. It is the means of opposing authoritarian rule in Asia and tyrannical warlords in Africa, and the basis of condemning North American policies over terrorist suspects in Guantanamo. Although there is a real problem relating to the enforcement of human rights, we cannot ignore the global growth of human rights under the umbrella of international law and international courts.

It is the case that one important source of human rights values, but not the only source, came from Christian values in general and from Thomist 'personalism' in particular. MacIntyre might therefore have found one antidote to nostalgia and the crisis of social solidarity in the 'integral humanism' of Jacques Maritain. This issue has recently been explored by Nicos Mouzalis [27] who in debating MacIntyres's Three Rival Versions of Moral Enquiry [28] suggests that the cultural contexts of moral debates are not as radically incommensurable as MacIntyre fears, precisely because the process of globalization has provided a counter-balance to such deep-seated diversity. Mouzalis praises MacIntyre for trying to develop moral arguments that are responsive to anthropological and sociological research and for maintaining his concern for moral arguments that are relevant to our times. MacIntyre has remained pessimistic about the prospects of establishing a moral framework that has some universal relevance while remaining sensitive to national or local cultures. For MacIntyre traditional Christian morality and natural law have been undermined by secularization [29]. Marxism, which could in principle offer a modern morality, has in fact always fallen back on some version of Kantianism or utilitarianism. Of course MacIntyre had departed from Marxism early in his career and in 'Notes from the Moral Wilderness' he had posed the problem of humanism in relation to Marxism [30]. The dilemma of where to find a moral basis to modern society has long haunted his work. Mouzalis offers a possible solution to MacIntyre's impasse by claiming that the almost universal acceptance of human rights suggests that the globalization of the principles of the Declaration of 1948 can overcome the erstwhile fragmentation and diversity of human cultures.

In our discussion of Mouzalis's proposal, we turn to a recent study by Samuel Moyn who in his account of the emergence of human rights presents two interconnected arguments [31]. First, he rejects the conventional interpretation in which human rights were the product of the immediate post-war period, specifically in response to the discovery of the victims of the Jewish Holocaust; and, second, he explores the paradox that human rights are never or rarely enforced outside or beyond the scope of the sovereign nation state. While human rights are addressed to humans rather than citizens, they cannot be enforced without the support of states. In Moyn's account, human rights eventually began to emerge on the political agenda as a consequence of growing dissatisfaction with the conventional the 
role of nation states in the international order and from a general recognition of the failures of state socialism. Human rights emerged as a useful ideology for a variety of very different social movements such as women's internationalism, for political dissidents in Poland and Hungary, and as the basis of NGO activity. The critical turning point in the history of human rights occurred when academic lawyers came to regard them as the basic normative framework of international law. These lawyers questioned the prevailing realist doctrines of international relations theory and as a result human rights were seen as part of their core business. Within international law and international legal institutions especially international courts, human rights could now play a significant role in modern politics.

Was this possibility - international law and human rights as the common basis of morality — not considered at all by MacIntyre? One figure who has been central to the growth of human rights and the re-assessment of natural law was Jacques Maritain (1882-1973) who was a major Roman Catholic philosopher in the Thomist tradition and who played a major role in the drafting of the Declaration of Human Rights. He stood out from critical social theorists in taking a predominantly positive view of the United States of America [32]. His Reflections on America warned against the dangers of a democracy based merely on the will and opinions of the majority and argued the case for a reconstruction of democracy based on natural law [33]. He was also supportive of Franklin D. Roosevelt's ambition to establish the principle that freedom of religion-so central to the AngloAmerican spirit - should be a basic right of all nations. For Maritain, however, such freedom was very different from the notion that every religious opinion was valid. Rather freedom of religion meant freedom for rational debate and dialogue, and hence it meant that the state should never coerce belief.

Critical of the underlying positivist empiricism of science and influenced by Henri Bergson, he mounted a critique of these dominant assumptions. Maritain was deeply influenced by both Aristotle and St. Thomas. The key issue in Thomism, as opposed to Augustinian Christianity, is that Aquinas did not see human nature as essentially evil. Following Aquinas, Maritain believed in the capacity of human reason to direct action. On these somewhat eclectic foundations (Bergsonian vitalism, Aristotle's virtue ethics and Thomist rationalism), Maritain came to develop 'integral humanism', which, while rejecting western secularism as barren, sought to construct a bridge between Thomist Christianity and politics [34]. In two works of political philosophy-The Rights of Man and Natural Law [35] and Christianity and Democracy [36] — he insisted that without a strong moral foundation democracy and freedom could never flourish. To overcome the limitations of secularism, the West required a re-vitalized Christianity that was founded on a proper appreciation of natural law and grasped the possibility of human rights as the modern expression of natural rights.

MacIntyre's intellectual foundations in Aristotle and Aquinas are more or less shared with Maritain. In After Virtue MacIntyre refers briefly to Maritain saying that he regards him 'with great respect' [37]. Clearly MacIntyre was influenced by Maritain, but there is an obvious difference between the two men. While Maritain worked hard to revise Thomism to have an impact on real politics and ensured that both Christianity and natural law had some direct relevance to the emergence of human rights, it is not clear how MacIntyre's world view could have concrete consequences for political reform. His nostalgic view of the world we have lost does not point towards any practical restoration of moral coherence or any repair of the social fabric. MacIntyre defended the importance of local communities in the struggle to achieved common goods, but there was no grand picture of international co-operation under the umbrella of international law and human rights [38]. 
Consequently his view of our condition remains pessimistic and bleak. Our children are confronted by 'a vestigial Christian vocabulary' and the 'absence of any alternative vocabulary' [39]. Despite the many problems - both practical and theoretical — that face the enforcement of human rights, they do offer an 'alternative vocabulary' which MacIntyre has failed to take into account.

\section{Conclusions}

We have considered recent debates about 'the end of the social', arguing that these discussions require a more rigorous definition of 'society'. We have outlined three prominent, and arguably 'classical', perspectives on society as structure, as solidarity and as creativity. Much of the apprehension about 'the end of the social' in both public and academic circles is in fact directed primarily at the idea of the loss of social solidarity, but some authors fear the loss of social structure as necessary condition for discipline in society. In some respects this is an old debate that has focused on the distinction between association and community. To further this discussion, we have concentrated on Alasdair MacIntyre's account of the loss of moral coherence and meaningful communities, resulting in a society that is 'after virtue'. MacIntyre is especially pertinent to the concerns of sociologists who want to reject much of the language of cultural relativism and who feel uncomfortable about the separation of facts and values, because he spent much of his academic career precisely challenging those arguments in for example Against the Self-Images of the Age [40].

However, we have criticized MacIntyre for his historical vision of past solidarities - a vision that we find both historically and sociologically questionable. Ethical disputes in medieval societies about the just wage for example suggest that moral uncertainty was prevalent in societies that MacIntyre characterizes as communal and coherent. MacIntyre appears to have a view of history as a dramatic transition from communities that enjoyed unquestioned social solidarity to a modern world of fragmented communities and inadequate moral traditions that cannot answer basic issues relating to human existence. This dichotomous view - a parallel to community and association in the work of Tönnies - is not satisfactory as an account of modern social change. We have also criticized his failure to recognize the possibility of new moral codes that attempt to grasp the consequences of globalization and the role of human rights in regulating — albeit often unsuccessfully —international affairs. Despite the fact that modern human rights have roots in Christian notions of human dignity and vulnerability, we suggest that human rights are now a global moral framework. We may plausibly regard the 'late' MacIntyre of After Virtue as a Thomist sociologist and therefore we have briefly compared his philosophical criticisms of value neutrality and relativism with the Thomist philosopher Jacques Maritain who played a role in the intellectual establishment of the human rights tradition.

While MacIntyre is nostalgic about society as solidarity, our brief excursus into human rights history via the contribution of Samuel Moyn suggest a more optimistic and less nostalgic vision of the present age. A Gemeinschaft-like vision of social solidarity may not be possible in a world increasing shaped by global communication on the Internet, but our account of human rights suggests that social relations are constantly created, repaired and recreated just as they are constantly corroded and undermined. This view of the ongoing nature of sociality is compatible with the Simmelian idea of society as a creative process or to use his neologism an example of Vergesellschaftung. While society as either structure or solidarity may be waning, society as creation is well illustrated by the attempt to 
build a world that is at least partially and intermittently regulated by shared norms regarding human dignity.

\section{References}

1. Turner, B.S. Introduction: A New Agenda for Social Theory? In The New Blackwell Companion to Social Theory; Turner, B.S., Ed.; Wiley-Blackwell: Oxford, UK, 2009; pp. 1-16.

2. Elliott, A.; Urry, J. Mobile Lives; Routledge: London, UK, 2010.

3. Simmel, G. Sociology: Inquiries into the Construction of Social Forms; Brill: Leiden, The Netherlands, 2009.

4. Simmel, G. The Metropolis and Mental life. In The Sociology of Georg Simmel; Wolff, K., Ed.; Free Press: New York, NY, USA, 1950; pp. 409-424.

5. Simmel, G. Essays on Religion; Yale University Press: New Haven, CT, USA, 1997; p. 24.

6. Turner, B.S. For Weber: Essays on the Sociology of Fate; Routledge and Kegan Paul: London, UK, 1981.

7. Offe, C. Reflections on America: Tocqueville, Weber and Adorno in the United States; Polity: Cambridge, UK, 2005.

8. Scaff, L.A. Max Weber in America; Princeton University Press: Princeton, NJ, USA, 2011.

9. Norton, R.E. Stefan Georg and his Circle; Cornell University Press: Ithaca, NY, USA, 2002.

10. Stones, R. Theories of Social Action. In The New Blackwell Companion to Social Theory; Turner, B.S., Ed; Wiley-Blackwell: Oxford, UK, 2009; pp. 83-105.

11. Giddens, A. The Constitution of Society: Outline of a Theory of Structuration; Polity: Cambridge, UK, 1984.

12. Bourdieu, P. Outline of a Theory of Practice; Cambridge University Press: Cambridge, UK, 1977.

13. Nisbet, R.A. The Sociological Tradition; Heinemann Educational Books: London, UK, 1966.

14. Durkheim, E. Professional Ethics and Civic Morals; Routledge: London, UK, 1992.

15. Pearce, F. The Radical Durkheim; Unwin Hyman: London, UK, 1989.

16. Jacobson, E. Metaphysics of the Profane: The Political Theology of Walter Benjamin and Gershom Scholem; Columbia: New York, NY, USA, 2003.

17. Rousseau, J.-J. The Social Contract and Discourses; J.M. Dent \& Sons: London, UK, 1973.

18. Rousseau, J.-J. Émile; J.M. Dent \& Sons: London, UK, 1993.

19. MacIntyre, A.C. After Virtue: A Study in Moral Virtue; University of Notre Dame Press: Notre Dame, IN, USA, 1984.

20. Abercrombie, N.; Hill, S.; Turner, B.S. The Dominant Ideology Thesis; Allen and Unwin: London, UK, 1980.

21. MacIntyre, A.C. Marxism - An Interpretation; SCM Press: London, UK, 1953.

22. MacIntyre, A.C. Marxism and Christianity; Penguin Books: Harmondsworth, UK, 1995.

23. Durkheim, E. The Elementary Forms of Religious Life; Oxford University: Oxford, UK, 2001.

24. Hervieu-Leger, D. Religion as a Chain of Memory; Polity: Cambridge, UK, 2000.

25. Turner, B.S. A Note on Nostalgia. Theor. Cult. Soc. 1987, 4, 147-156.

26. Nisbet, R.A. Society. In The Blackwell Companion of Modern Social Thought; Outhwaite, W., Ed.; Blackwell: Oxford, UK, 1993; pp. 640-642. 
27. Mouzalis, N. Encyclopedia, Genealogy and Tradition: A Sociocultural Critique of MacIntyre's Three Moral Discourses. Sociol. Rev. 2011, 95, 1-16.

28. MacIntyre, A.C. Three Rival Versions of Moral Enquiry.Encyclopedia, Genealogy and Tradition; Notre Dame University Press: Notre Dame, IN, USA, 1990.

29. MacIntyre, A.C. Secularization and Moral Change; University Press: Oxford, UK, 1967.

30. MacIntyre, A.C. Notes from the Moral Wilderness. The New Reasoner nos 7 and 8. 1958-1959. Reprinted in The MacIntyre Reader; Knight, K., Ed.; University of Notre Dame Press: Notre Dame, IN, USA, 1998a; pp. 31-49.

31. Moyn, S. The Last Utopia: Human Rights in History; The Belknap Press of Harvard University Press: Cambridge, MA, USA, 2010.

32. Howard, T.A. God and the Atlantic: America, Europe and the Religious Divide; Oxford University Press: Oxford, UK, 2011.

33. Maritain, J. Reflections on America; Charles Scribner's Sons: New York, NY, USA, 1958.

34. Maritain, J. Integral Humanism: Temporal and Spiritual Problems of a New Christendom; Scribner's Sons: New York, NY, USA, 1968.

35. Maritain, J. Rights of Man and Natural Law; Ignatius Press: San Francisco, CA, USA, $1986 a$.

36. Maritain, J. Christianity and Democracy; Ignatius Press: San Francisco, CA, USA, 1986 .

37. MacIntyre, A.C. After Virtue: A Study in Moral Virtue; University of Notre Dame Press: Notre Dame, IN, USA, 1984; p. 260.

38. MacIntyre, A.C. Dependent Rational Animals: Why Human Beings Need the Virtues; Duckworth Press: London, UK, 1999; p. 142.

39. MacIntyre, A.C. Secularization and Moral Change; Oxford University Press: Oxford, UK, 1967; p. 36.

40. MacIntyre, A.C. Against the Self-images of the Age: Essays on Ideology and Philosophy; Schocken Books: New York, NY, USA, 1971.

(C) 2012 by the authors; licensee MDPI, Basel, Switzerland. This article is an open access article distributed under the terms and conditions of the Creative Commons Attribution license (http://creativecommons.org/licenses/by/3.0/). 